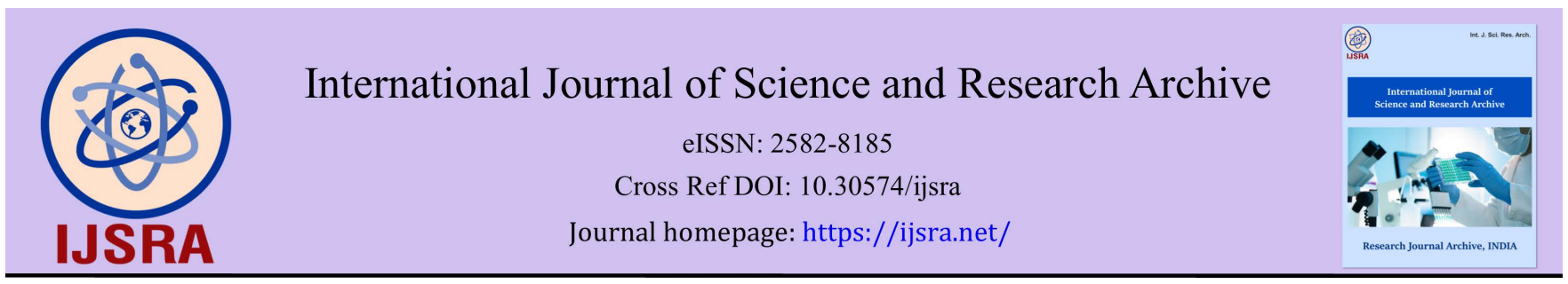

(RESEARCh ARTICLE)

\title{
The growth and production of field rice (Oryza sativa l.) Inpari 9 and Mentik Wangi variety on peat land and peat buried
}

\author{
Hapsoh, Wawan, Arnis En Yulia, Isna Rahma Dini * and Fhingky Olivia Tiara Sakti \\ Department of Agrotechnology, Faculty of Agriculture, Riau University, Pekanbaru, Riau, Indonesia.
}

International Journal of Science and Research Archive, 2021, 04(01), 136-148

Publication history: Received on 29 September 2021; revised on 15 November 2021; accepted on 17 November 2021

Article DOI: https://doi.org/10.30574/ijsra.2021.4.1.0170

\begin{abstract}
Rice plant is paddy producing plant needed by most of Indonesians as staple food. Sei Geringging Village in Kampar District, Kampar Kiri Sub-District had technically irrigated field on peat land and peat buried. Farmers on Sei Geringging Village farmed 2 kinds of rice which were prime variety and local variety. Most of prime variety farmed was Inpari 9 and the local variety was Mentik Wangi. Farmers on Sei Geringging Village had been farming the rice without knowing which variety had been best to farm on peat land and on peat buried that the yield had not been optimal. This research aimed to know the comparison of maximum growth and production rate of Inpari 9 and Mentik Wangi variety rice on peat land and peat buried. This research was done by a survey with descriptive method .Treatment combination was repeatedly done 4 times resulting 16 unit trial squares. Each square had 5 sample plants. Best growth was on peat land that planted with the Inpari 9 variety and on peat buried was planted with Mentik Wangi variety resulting yield of 4,20 ton.ha-1
\end{abstract}

Keywords: Paddy; variety; Inpari 9; peat; peat buried

\section{Introduction}

Rice plant is paddy producing plant needed by Indonesians as the source of staple food. [1] said that rice contains 49,6 $\mathrm{g}$ of carbohydrates, 4, $10 \mathrm{~g}$ of proteins, 0,205 g of fats, $232 \mathrm{~g}$ of calories and 0, $74 \mathrm{~g}$ of fibre. Based on data from BPSStatistics of Riau [2] in 2017, the total range of rice field in Riau Province on 2015 was 114,354 Ha. Kampar District on 2015 placed on $4^{\text {th }}$ position from total 12 districts in Riau Province that had the total range of rice field of 10,284 Ha. Sei Geringging Village was one of the villages in Kampar District, Kampar Kiri Sub-District that had technically irrigated their rice fields. [3] said that irrigated rice field is important due to the adequate availability of water as the main factor for cultivating the plants.

Sei Geringging Village has peat soil and peat buried kind rice fields. According to Notohadikusumo [4], peat is the kind of soil constructed from the remains of dead plants that makes it have high level of organic content. While the peat buried is the peat soil heaped or stacked by the mineralized soil [5].

Farmers in Sei Geringging Village farmed 2 kinds of rice which are prime and local varieties. According to Hanum [6] the prime variety is important in increasing the yield, improving and quality diversification, and yield lost prevention due to pests, disease, and environmental hazard. According to Supangkat [3] the existence of local variety at this time is not significantly taken into account due to the high profile of the plant. Local variety has high adaptive measurements to the local soils. Local variety needs to be maintained and sustained as the local assets of germplasm, also as the source of genetical variety.

\footnotetext{
* Corresponding author: Isna Rahma Dini

Department of Agrotechnology, Faculty of Agriculture, Riau University, Pekanbaru, Riau, Indonesia.

Copyright $(2021$ Author(s) retain the copyright of this article. This article is published under the terms of the Creative Commons Attribution Liscense 4.0.
} 
The prime variety, most planted by Sei Geringging Village's farmers, was Inpari 9 and the local variety was Mentik Wangi. Farmers in Sei Geringging Village planted rice without knowing which rice variety was suitable for planting on peat soils and on peat buried soils so that the production yields had not been optimal. Not all rice varieties can adapt certain environments, because each variety has its own growing conditions. The aim of this research is to determine the comparison of the best growth and production of Inpari 9 and Mentik Wangi rice variety in peat and peat buried soils.

\section{Material and methods}

\subsection{Research Site}

The research was conducted in Sei Geringging Village, Kampar Kiri Sub-District, Kampar District, and Riau Province. Soil analysis was carried out at Central Plantation Services Laboratory, Pekanbaru.

\subsection{Research Design}

This research was conducted in a survey with the standard deviation method. As for the implementation techniques was carried out by observations and interviews. The research area was randomly selected stratified (Stratified Random Sampling) It is based on peat land types and buried peat. For farmer respondents was deliberately selected (Purposive Sampling) based on rice varieties grown with a minimum area $1000 \mathrm{~m}^{2}$. Combination treatment, i.e.:

P1= Peat Soil + Inpari 9 Variety

P2= Peat Soil + Mentik Wangi Variety

P3= Peat buried Soil + Inpari 9 Variety

P4= Peat buried Soil + Mentik Wangi Variety

The combination of those treatments was repeated 4 times, then 16 units of test plots were obtained. Each plot has 5 sample plants so that there were 80 sample plants in total.

\subsection{Statistical Analysis}

The data obtained were analyzed statistically by SPSS Alication. The linear model was as follows:

$$
\mathrm{Y}=\mu+\mathrm{SD}
$$

Information:

$\mathbf{Y}=$ Observation value

$\boldsymbol{\mu}=$ Average value

SD = Standard deviation

\section{Results}

Planting of paddy rice on peat and peat soil buried with Mentik Wangi varieties produced the highest plant height of 77,97 and $92,68 \mathrm{~cm}$ (Figure 1)

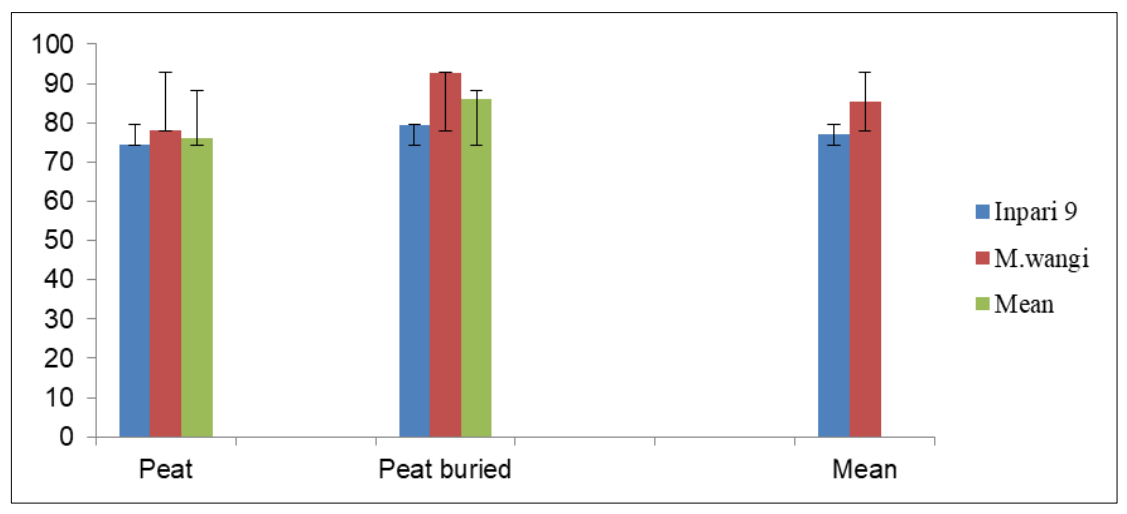

Figure 1 Plant height $(\mathrm{cm})$ of Inpari 9 and Mentik Wangi rice variety on peat soil and Peat buried 
Plant height in Inpari 9 and Mentik Wangi varieties based on the description (Apendix A and B) shows that plant height has not reached its maximum growth. Plant height that was still below the description was thought to be due to low soil fertility level (Table 1).

Table 1 Results of the analysis of peat and heaped up peat soil in the village of Sei Geringging

\begin{tabular}{|l|l|c|l|c|l|}
\hline No & Parameters & Heaped Up Peat Soil & Value* & Peat Soil & Value* $^{*}$ \\
\hline 1. & $\mathrm{pH}\left(\mathrm{H}_{2} \mathrm{O}\right)$ & 5,42 & Acidic & 5,02 & Acidic \\
\hline 2. & N Total $(\%)$ & 0,5 & Intermediate & 1,21 & Very High \\
\hline 3. & P Available & 97,73 & Very High & 48,6 & Very High \\
\hline 4. & K Available & 0,13 & Very Low & 0,16 & Very Low \\
\hline
\end{tabular}

Source: Central Plantation Services Laborato-ry [7]

* Values based on soil chemical properties assessment criteria in Table 2.

Table 2 Criteria for assessing soil chemical properties

\begin{tabular}{|l|l|l|c|c|c|c|}
\hline \multirow{2}{*}{ No } & \multirow{2}{*}{ Parameters } & \multicolumn{5}{|c|}{ Value } \\
\cline { 3 - 7 } & & Very Low & \multicolumn{1}{|c|}{ Low } & Intermediate & \multicolumn{1}{c|}{ High } & \multicolumn{1}{c|}{ Very High } \\
\hline 1. & \multirow{2}{*}{$\mathrm{pH}\left(\mathrm{H}_{2} 0\right)$} & $<4,5$ & $\begin{array}{l}4,5-5,5 \\
\text { Very Acidic }\end{array}$ & $\begin{array}{l}5,5-6 \\
\text { Acidic }\end{array}$ & $\begin{array}{l}6,6-7,5 \\
\text { Rather Acidic }\end{array}$ & $\begin{array}{l}\text { Neutral } \\
7,6-8,5 \\
\text { Rather Alkali }>8,5 \text { Alkali }\end{array}$ \\
\hline 2. & N Total (\%) & $<0,1$ & $0,1-0,2$ & $0,21-0,5$ & $0,51-0,75$ & $>0,75$ \\
\hline 3. & P Available & $<4$ & $5-7$ & $8-10$ & $11-15$ & $>15$ \\
\hline 4. & K Available & $<5$ & $5-16$ & $17-24$ & $25-40$ & $>40$ \\
\hline
\end{tabular}

Planting of Inpari 9 varieties on buried peat and peat soil resulted in the highest number of tillers, namely 14,30 and 13,04 stems (Figure 2). Differences in varieties consisting of prime variety and local variety are thought to be due to genetic factors.

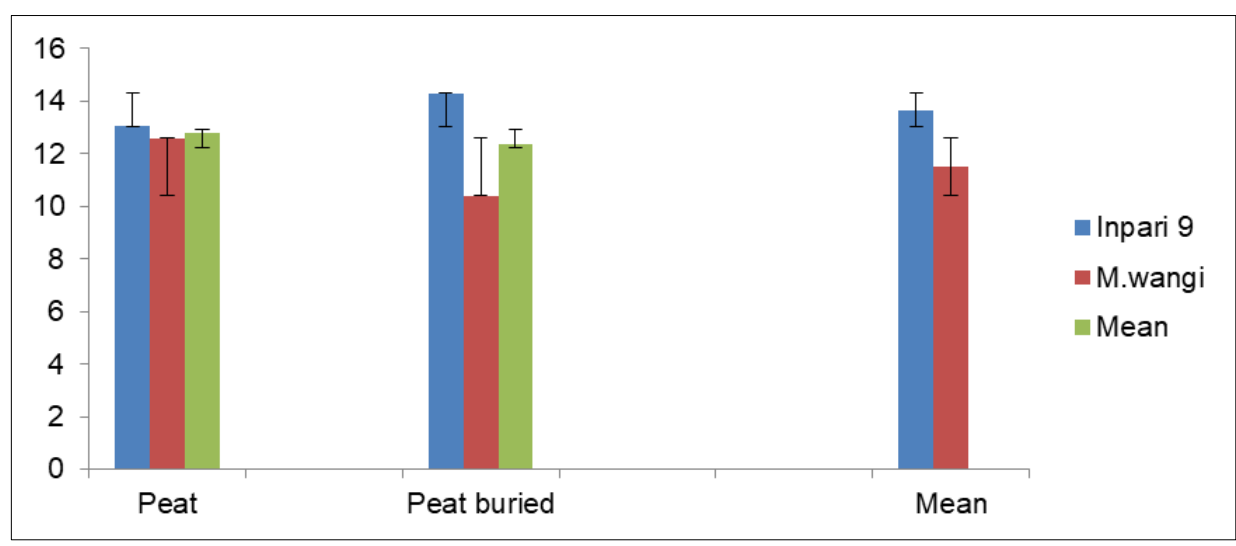

Figure 2 The maximum number of tillers (stems) of Inpari 9 and Mentik Wangi rice variety on peat and Peat buried

Planting of Inpari 9 varieties on peat and peat soil was buried resulting in the highest number of productive tillers, namely 8,19 and 9,77 (Figure 3). This result is the same as the maximum number of tillers in planting Inpari 9 variety on peat buried soil (Figure 2).

Planting of Inpari 9 varieties on buried peat and peat soils produced the highest panicle lengths of 21.85 and $22.80 \mathrm{~cm}$ (Figure 4). This was allegedly due to genetical factor that was variety and environmental factor that was the soil. 


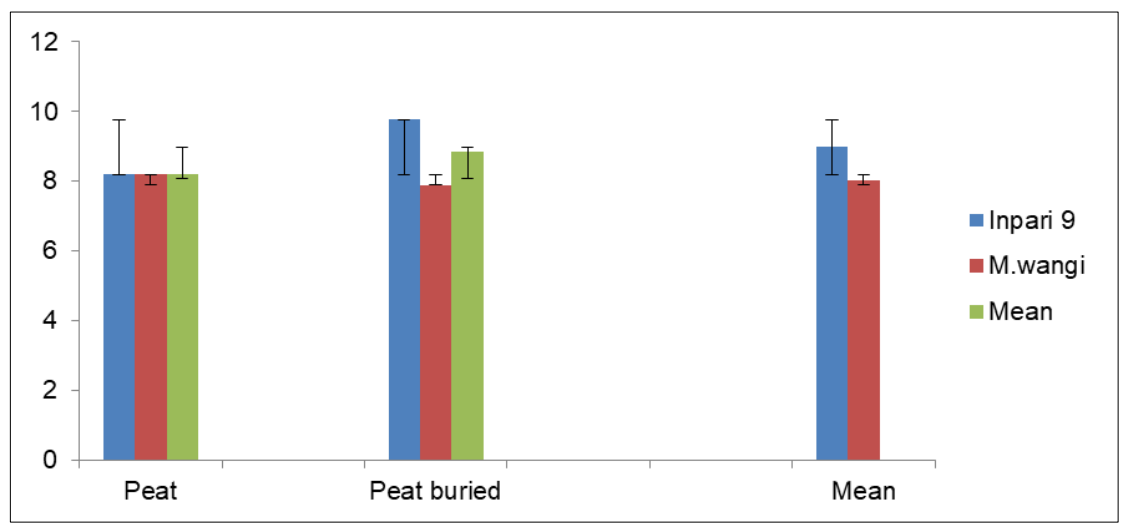

Figure 3 The number of productive tillers (stems) of Inpari 9 and Mentik Wangi rice variety on peat and Peat buried

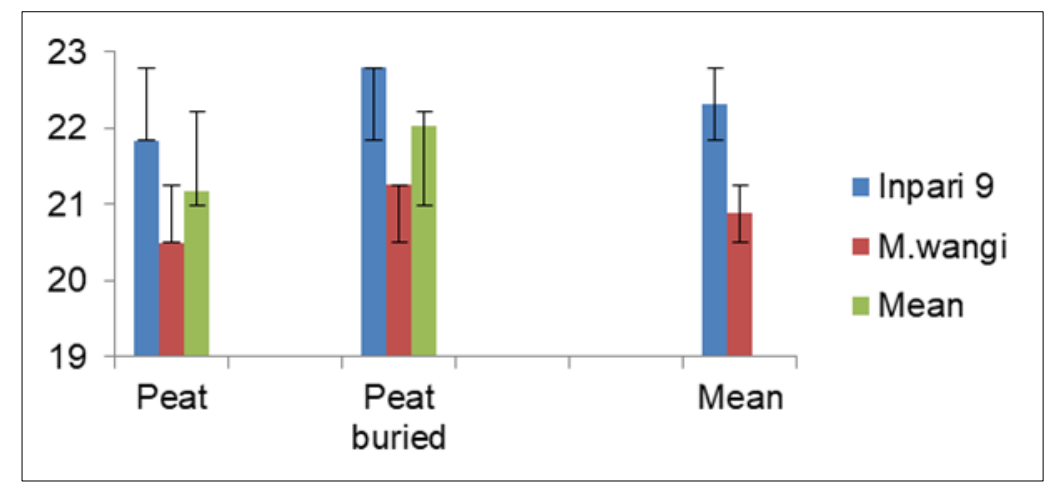

Figure 4 Panicle length (cm) of Inpari 9 and Mentik Wangi rice variety on peat and Peat buried

Planting of Inpari 9 varieties on peat soil is Mentik Wangi which is 85, 95 and buried peat is Inpari 9 which is 93,10 (Figure 5). This is allegedly due to genetic and environmental factors.

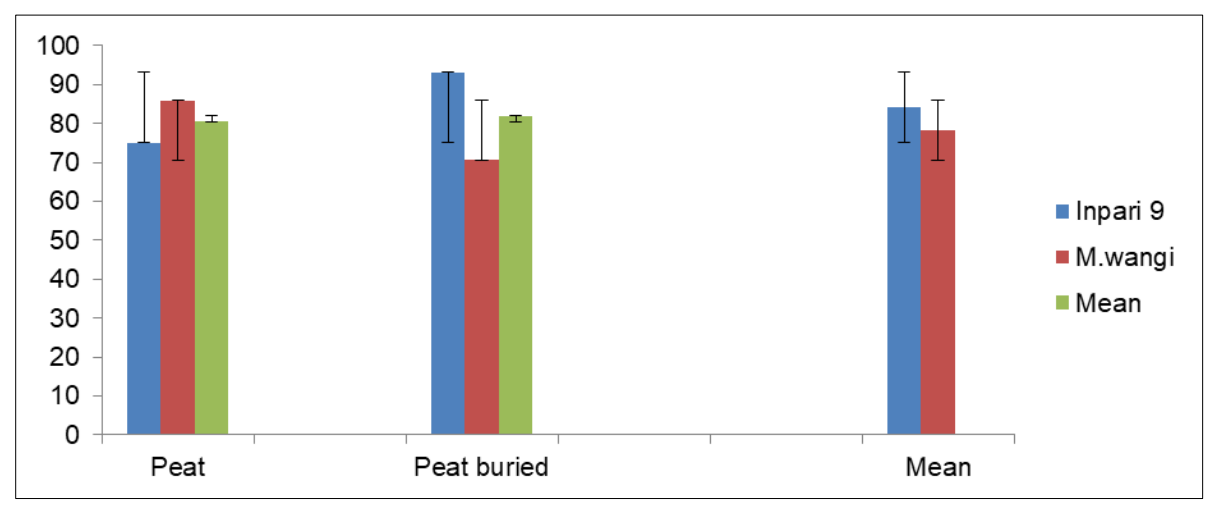

Figure 5 The number of branches of panicles per clump of Inpari 9 and Mentik Wangi rice variety on peat and Peat buried

Planting of Mentik Wangi varieties on peat soil and buried peat has the fastest harvesting age of 97, 00 and 91, 00 days (Figure 6).

Planting of Mentik Wangi varieties on peat and peat soil was buried resulting in the highest percentage of rice grain, which was $65,75 \%$ and $75,50 \%$ (Figure 7). This was allegedly due to genetic and environmental factors.

Planting the Mentik Wangi variety on peat soil and buried peat produced the highest 1000 grain weights, namely 24.82 and $27.09 \mathrm{~g}$ (Figure 8). This is allegedly due to genetic and environmental factors. 


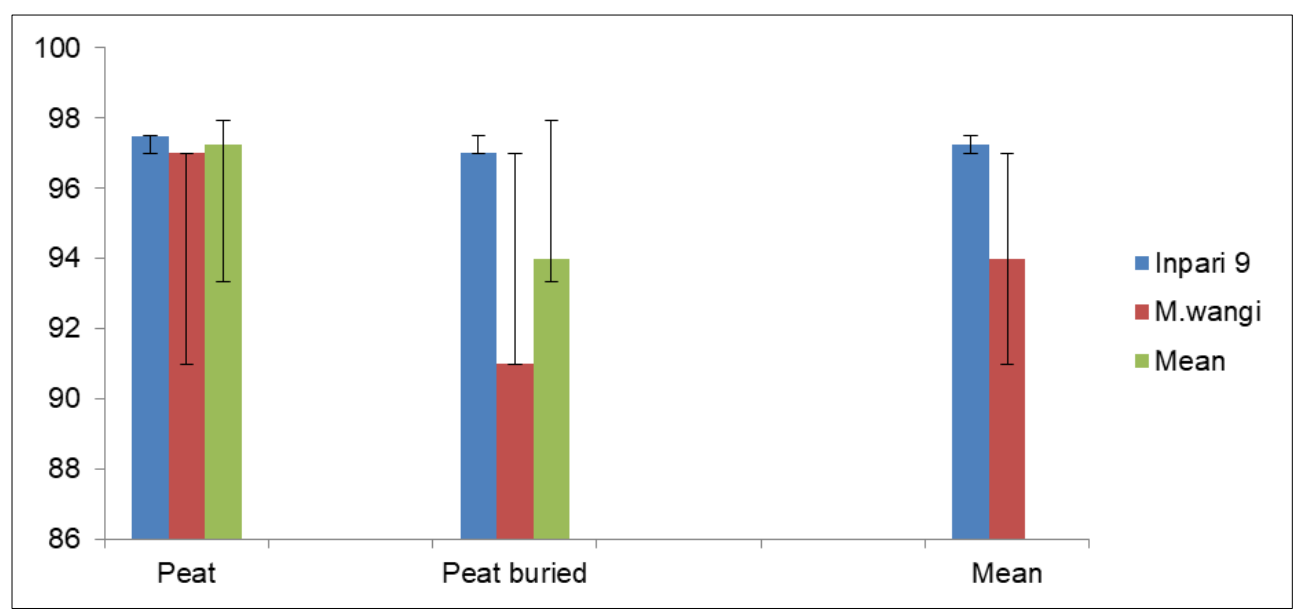

Figure 6 Harvest age (days) of Inpari 9 and Mentik Wangi rice variety on peat and Peat buried

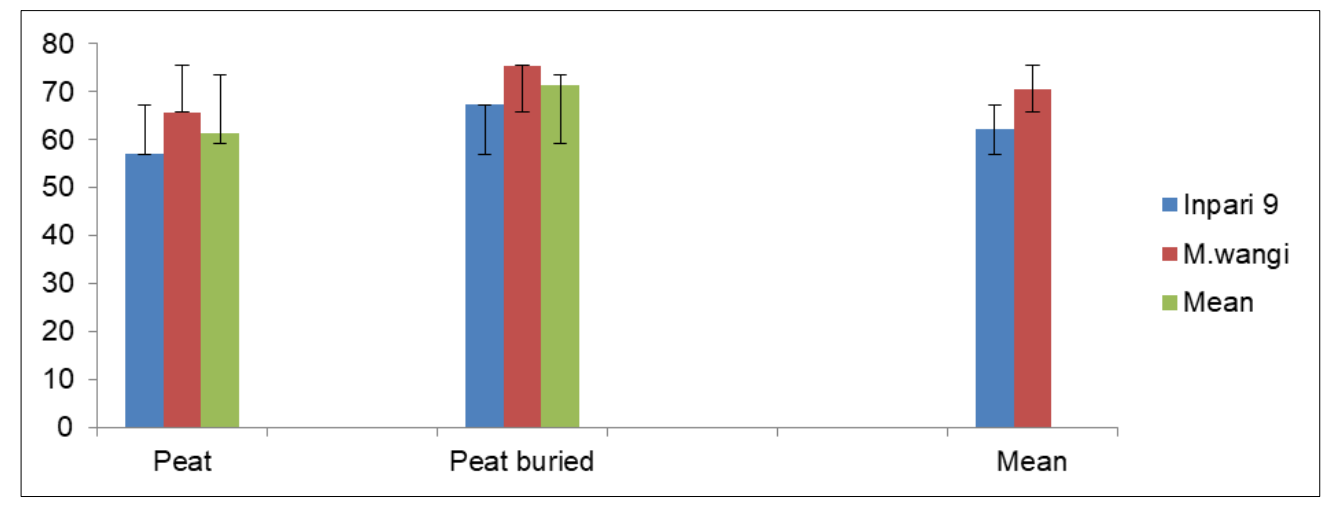

Figure 7 Percentage of filled grain (\%) in Inpari 9 and MentikWangi rice variety on peat and Peat buried

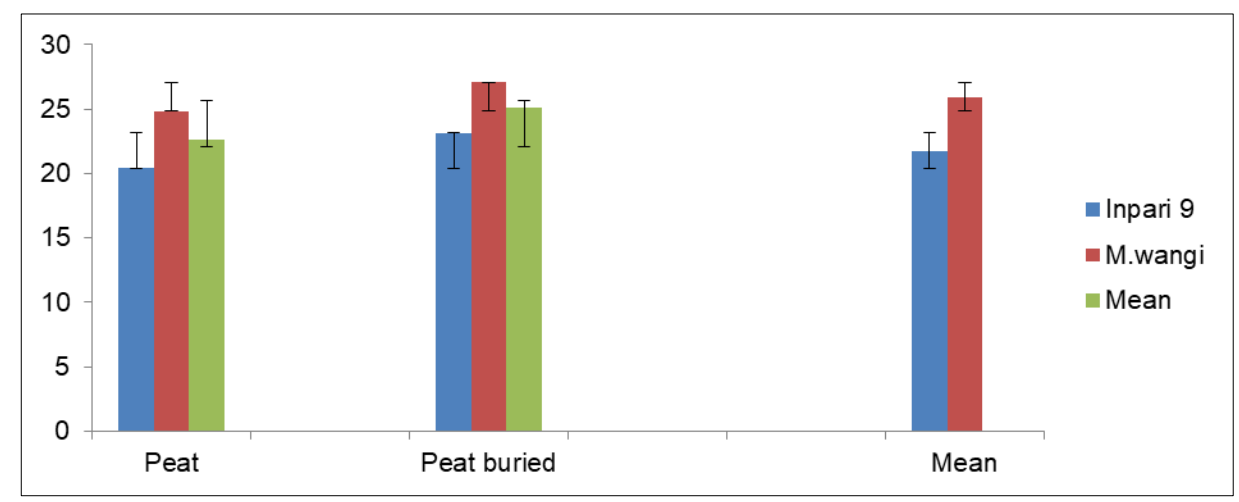

Figure 8 Weight of 1000 grains (g) of Inpari 9 and Mentik Wangi rice variety on peat and Peat buried

Planting of Mentik Wangi varieties on buried peat and peat soils has the highest yields of 6.88 .00 or 3.46 ton.ha1 and 838.802 g.m ${ }^{-2}$ or 4.20 ton.ha ${ }^{1}$ (Figure 9). This is allegedly due to genetic and environmental factors. 


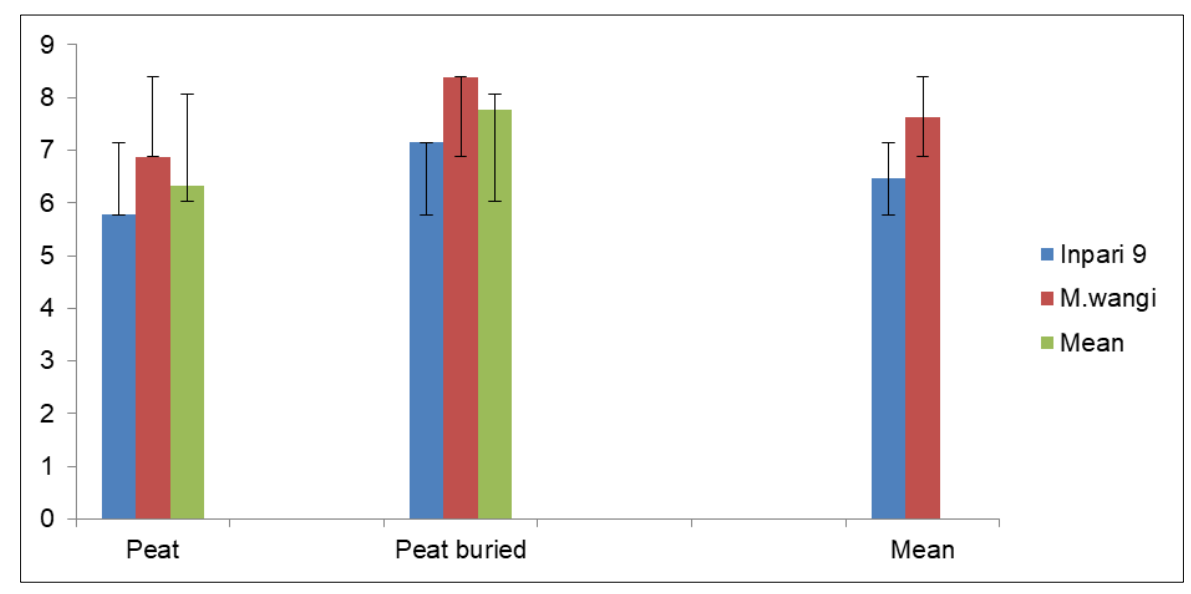

Figure 9 Milled dry grain weight per seed (g.m $\mathrm{m}^{-2}$ ) of Inpari 9 and Mentik Wangi rice variety on peat and Peat buried

\section{Discussion}

\subsection{Plant Height}

Plant varieties have different properties or characters. The plant height result Mentik Wangi variety on peat buried soil was higher compared to other varieties and the soil was suspected because the Mentik Wangi variety is a local variety which generally has a higher plant height than the prime variety that has undergone selection process. According to Utama [8], the prime variety produces shorter plants and [9] said that Indonesian local varieties generally have a higher plant profile so that they were likely easy to fall down. The height of the plant is influenced by the characteristics that affect the yield result potential of one variety [10]. The shorter varieties would absorb more sunlight than taller one.

The peat buried soils have a higher $\mathrm{pH}$ and $\mathrm{P}$ available than peat soil (Table 1). According to Lubis et al [11], soil pH was very influential in plant growth, such as the availability of nutrients. Soil acidity is one of the most important factors in the soil [12]. Soil pH could affect the soil nutrient availability and can be a factor related to the soil quality and inhibitor factors for plant growth and production. The optimum availability of some nutrients in the soil was influenced by pH. At $\mathrm{pH}$ less than 5.5 phosphate ions would be bound by Fe and $\mathrm{Al}$ as compounds that are not soluble in water, whereas above $\mathrm{pH} 7.0$ would react with $\mathrm{Ca}$ and $\mathrm{Mg}$ to form compounds that were not soluble in water and nutrients phosphorus (P) to be not available to the plants. Phosphorus is an essential nutrient for plants. There was no other element that could replace its function in plants, so plants must get enough $\mathrm{P}$ nutrients for their growth.

\subsection{Maximum till Amount}

According to Fauziah [13], New Prime Variety (NPV) is a group of rice that have many tillering characteristics (more than 20 shoots per clump) and according to [9] Indonesian local varieties generally have a small number of tillers.

According to Arraudeau and Vergara [14], the ability of each variety is different in producing tillers, this is caused by the genetic factors possessed by each of the different varieties [14]. [15] stated that the number of maximum tillers and productive tillers is strongly influenced by varieties that have more adaptation to the environment. [16] also argue that the number of tillers and adaptability is different from each variety because the difference in each variety is determined by the interaction between the genotype and the beneficial environment or according to the growth and development of the rice itself.

\subsection{Number of productive tillers}

The results of productive tillers would be in line with the maximum tillering results. The more the maximum number of tillers, the more the number of productive tillers would be. This was suitable with the opinion of Arraudeau and Vergara [14] that the number of productive tillers produced is a reflection of the maximum number of tillers.

According to Atman and Yardha [17], the formation of the number of productive tillers was closely related to the maximum number of tillers, the more the number of maximum tillers, the more the number of productive tillers. [18] also argues that the number of productive tillers is tillers that develop further and produce panicles. 


\subsection{Panicle Length}

In accordance with the opinion of Taslim et al [19] result components such as panicle length were influenced by genetical factors and environmental factors. Sometimes these genetic traits did not arise because environmental factors were not aropriate, so human efforts in utilizing environmental factors were required so that genetic traits were expected to emerge.

Peat soil has $\mathrm{pH}$ and $\mathrm{P}$ which was lower than peat buried soil (Table 1). Soils that have acidic $\mathrm{pH}$ would affect plant roots in absorbing nutrients needed for the plants, and if the nutrients needed by plants were not met, it would certainly disrupt the growth and development of the plants. In accordance with the opinion of Sudaryono [20], the optimum availability of some nutrients in the soil was influenced by $\mathrm{pH}$. Soil acidity is one of the most important factors in the soil. The biggest general effect of $\mathrm{pH}$ on plants is its effect on the availability of nutrients in the soil.

The low $\mathrm{P}$ available on peat soil is influenced by the low $\mathrm{pH}$ of the soil. This is suitable with Aksani's opinion that high soil acidity affects the balance of chemical reactions in the soil and the availability of nutrients in it especially phosphate [21]. Phosphorus is an essential nutrient for plants. There is no other element that can replace its function in plants, so plants must get enough P nutrients for their growth. [20] describes the important function of phosphorus nutrients for plants, namely in the process of photosynthesis, respiration, transfer and energy storage, cell division and enlargement and other metabolic processes of plants.

\subsection{The number of branches of panicles per clump}

In accordance with the opinion of Hutasoit et al [22], the number of panicle branches depends on rice varieties and the genetics of the plants themselves. [23] also argue that each rice variety has its own characteristics and depends on the genetic traits contained in each variety.

The highest number of panicle branches per clump was the same as that found in the highest panicle length treatment. This was in accordance with the opinion of Sitinjak and Idwar [24] that every increase in panicle length will grow grain stalk branches that produce more grain.

The $\mathrm{pH}$ and $\mathrm{P}$ content on peat buried soil is higher than it is in peat soil (Table 1). This is thought to be the cause of the high result of branches of panicles per clump on peat buried soil. According to Adimihardja [25], one of the factors that determines the ability of plants to absorb nutrients is the level of nutrient availability which is influenced by the level of soil acidity. Availability of nutrients in the soil promotes increased nutrient absorption by plants.

According to Sumardi et al [26], panicle state and the number of panicle branches are the result of interactions between genetic factors and growing environmental factors during the process of growth and development takes place. After the primordial shaped formed, environmental factors will not change the number of panicle branches that have been formed, but the environment will affect the final size. If the environment it receives is a driver of the ongoing growth process, then the possibility that the panicle size occurs will be longer and the number of panicle branches formed would mostly be filled into a grain. Likewise, vice versa, if the environmental factors received were inhibiting growth, the panicles that come out would be shorter and the panicles that have been formed were many that were not filled

\subsection{Harvest Age}

Based on the description of the plant, the Inpari 9 variety is nearing the harvest age in the description, which is 125 days (Aendix A). However, the harvest age of the Mentik Wangi variety based on the description is still not in accordance with the harvest age obtained from the results of the research. This is allegedly due to genetic and environmental factors. In accordance with the opinion of Manurung [27] that the harvest age can be determined by the phase of good vegetative growth and a good generative phase.

Mentik Wangi variety which is a local variety that has better adaptability to the environment than Inpari 9 variety which is prime variety. In accordance with the opinion of Anhar et al [28] local varieties, naturally tested for their resistance to various environmental stresses and pests and diseases so that local variety is a priceless collection of genetic resources.

The difference in harvest age is far from the description, presumably because the results obtained in the description are in the optimum conditions of the plant, whereas in the research carried out is on acidic soil conditions and lack of nutrients (Table 1). According to Anhar et al [28] the characteristics of prime variety requires more intensive treatment than local variety to achieve its optimal results. 
The harvest age of the Mentik Wangi variety which is faster than the Inpari 9 variety is suspected because the Mentik Wangi variety was better able to absorb nutrients even in acidic soils so that growth and development is faster than the Inpari 9 variety. In the opinion of Susanto et al [29] superior varieties require more nutrients to suort high growth and yield. According to Efendi and Simanjuntak [30], basically each variety has its certain characteristics. Local rice variety has the potential to grow and produce which is able to match the prime variety, especially in a climatic environment.

\subsection{Filled Grain Percentage}

In accordance with the opinion of Darti [31] that the properties of each genetic and environmental place of growth of the varieties, would affect the grain density of each panicle, the number of grains per panicle will also affected the amount of grain formed.

According to Sitinjak and Idwar [24] that the difference in percentage of rice grain is also affected because each variety has different genetic factors in flower formation in each panicle, seeds are formed and the seeds are filled or not. According to Gardner et al [32], genetic factors relates to the ability of rice plants to optimize its production in regulating seed filling by allocating photosynthesis results quickly, so that the suly of photosynthesis into seeds becomes adequate and finally the seeds become stale.

Peat buried soils has high $\mathrm{P}$ available compared to peat soil (Table 1). P element would increase the absorption of nutrients which would affect the formation of grain. In accordance with the opinion of Leiwakabessy [33] stated that the sufficient $\mathrm{P}$ elements makes plants able to develop more roots, if more roots are formed, more nutrients were absorbed. According to Sutedjo [34], P elements in plants can stimulate flower and grain formation, so that P elements are needed in large amount.

\subsection{Weight of 1000 grains}

In accordance with the opinion of Sitinjak and Idwar [24], genetic factors affected the weight of 1000 seeds because it is related to the shape and size of seeds. [35] also argue that the weight of 1000 seeds is more determined by the ability of filling the grains which varies between varieties. This process is related to the distribution of carbon to the grain which is influenced by the balance of starch-sucrose and involves the activity of the sucrose phosphate synthase enzyme.

The results of soil analysis (Table 1) pH and $\mathrm{P}$ that are available on peat buried soil was higher than peat soil. A low $\mathrm{pH}$ will affect the availability of $\mathrm{P}$, which helps plants provide the nutrients needed by it. In accordance with the opinion of Sasmita and Tjahjana [36] a low pH can indicate low nutrient solubility especially $\mathrm{P}$ because there is a $\mathrm{P}$ bond by $\mathrm{Al}$ and Fe so that it was less available for plants. According to Satria et al [37], P element stimulates plant roots so that the roots are better at absorbing nutrients that utilized by plants.

According to Taufik et al [38] that by increasing the nutrient uptake, nutrient requirements are more fulfilled and the metabolism runs optimally so that the formation of proteins, carbohydrates, and starch is not inhibited, consequently the accumulation of metabolic materials in seed formation increases so that the seeds formed have a larger size and weight.

\subsection{Dry Grain Grain per Plot}

In accordance with Kamal [39] the difference in total results is caused by differences in the genetic composition of each rice cultivar, so that the response to the environment is also different. Not only genetic, environmental factors also influence the plant production capacity.

Based on the description, Mentik Wangi variety (Aendix B) has obtained results that exceed the description of $838.80 \mathrm{~g}$ or 4.20 ton.ha ${ }^{1}$ but the Inpari 9 variety (Aendix A) is very far from the results specified in the description which is 715.00 g or 3.58 ton.ha ${ }^{1}$. This is suspected even though the Inpari 9 variety is a superior variety that has high production, but if the conditions are not optimum and the soil with nutrient content was not maxismally fulfilled it will still produce low production. In accordance with the opinion of Sari at al [40] to obtain maximum production from superior varieties of rice, must be planted optimally, that is on fertile land, nutrients must be available, adequate irrigation, soil should contain organic matter, integrated pest control, and processing of plants must be done well ( $7-12$ tons.ha-1).

Peat and peat buried soils are soils with low nutrient content (Table1). One that affects nutrient absorption is pH, which also affects production. In accordance with the opinion of Subandi et al [41] a high pH value could affect the availability of nutrients that would be absorbed by the roots. According to Sasmita and Tjahjana [36] low pH is one of the limiting factors of production because the increase in $\mathrm{pH}$ would be in line with the increase in production. 
The high yields obtained from planting Mentik Wangi variety on peat buried soil are in line with the high yield of pithy grain weight (Table 1) and 1000 grain weight (Figure 8). In accordance with Zen [42] opinion, the increase in yield of rice in each clump is obtained from grain weight, grain per panicle and high-pitched grain.

Inpari 9 variety was planted on peat buried soil in the observation parameters of the maximum number of tillers, number of productive tillers, panicle length and number of panicles per clump had the highest yield, and Mentik Wangi variety planted on peat buried soil in parameters of grain weight and weight 1000 items had the highest yield. This results in milled dry grain weight amount per plot being was not significantly different, because the number of maximum tillers, number of productive tillers, panicle length and the number of branches of panicles per tall clump does not necessarily produce a lot of grain and 1000 grains weight amount. This is in accordance with the opinion of Hambali and Iskandar [43] that the longer the average length of panicle rice, the more the amount of grains are produced, however it does not always provide high yields because it is also influenced by the percentage of filled grain and empty grain.

[44] stated that rice production is determined, among others, by the percentage of rice grain. The higher the yield components, the plant will also provide higher production. Furthermore, [45] stated that one of the factors that influence the increase in yield is the increase in the value of growth components and components of crop yields, including the number of grain per panicle and the percentage of filled grains.

\section{Appendix A}

Description of Inpari 9 rice variety

\begin{tabular}{|c|c|}
\hline Plant Age & 125 days \\
\hline Plant Shape & Upright \\
\hline Plant Height & $105-121 \mathrm{~cm}$ \\
\hline Productive Tiller & $16-22$ stems \\
\hline Foot Color & Green \\
\hline Stem Color & Green \\
\hline Leaf Ear Color & White \\
\hline Leaf Tongue Color & Green \\
\hline Leaf Color & Green \\
\hline Leaf Surface & Rough \\
\hline Leaf Position & Upright \\
\hline Leaf Flag & Upright \\
\hline Grain Shape & Long and $\operatorname{sim}(\mathrm{L}=6,78 \mathrm{~mm} ; \mathrm{W}=2,12 \mathrm{~mm} ; \mathrm{L} / \mathrm{W}=3,21)$ \\
\hline Grain Color & Clear Yellow \\
\hline Loss Rate & Intermediate \\
\hline Rice Texture & Fluffier \\
\hline Amylose Content & $21 \%$ \\
\hline 1000 Grains Weight & $23,3 \mathrm{~g}$ \\
\hline Yield Average & $6,25 \mathrm{t} / \mathrm{ha}$ \\
\hline Yield Potential & $9,9 \mathrm{t} / \mathrm{ha}$ \\
\hline Resistance To Disease & $\begin{array}{l}\text { Slightly susceptible to WBC pests biotypes } 1,2 \text { and } 3 \text { Slightly resistant to race III HDB } \\
\text { disease and somewhat vulnerable race IV and VIII, rather resistant to tungro inoculum } \\
\text { disease No.73, and resistant to tungro inoculum disease no.031 and no. } 013\end{array}$ \\
\hline
\end{tabular}




\begin{tabular}{|l|l|}
\hline Prompts for planting & Suitable to be planted in irrigated land with altitudes up to $600 \mathrm{~m}$ above sea level \\
\hline Reason released & Tungro resistant, fluffier rice, high yield potential \\
\hline
\end{tabular}

Source: [46]

\section{Appendix B}

Description of Mentik Wangi rice variety

\begin{tabular}{|l|l|}
\hline Accession No. & 1754 \\
\hline Accession Name & Mentik wangi \\
\hline Origin Province & Central Java \\
\hline Origin District & Magelang \\
\hline Habitus & Intermediate \\
\hline Plant Age & $112-113$ HST \\
\hline Average Plant Height & $106-113$ cm \\
\hline Amount of vegetatif tiller & 15 \\
\hline Amount of productive tiller & 14 \\
\hline Leaf Color & Green \\
\hline Foot Color & Goldie Yellow \\
\hline Leaf Tongue Color & White \\
\hline Leaf Ear Color & Uncolored \\
\hline Leaf Neck Color & Light Green \\
\hline Leaf Surface & Unharied \\
\hline Leaf Flag Position & Flat \\
\hline 1000 Grains Weight & 18 gram \\
\hline Average Yield & 4,18 ton/ha \\
\hline
\end{tabular}

\section{Conclusion}

- The best growth of rice is on peat buried soil planted with Inpari 9 variety.

- The best production capacity of rice is on peat buried soil planted with Mentik Wangi variety which produced 838.80 g.m-2 or $^{4} .20$ ton.ha-1

\section{Compliance with ethical standards}

\section{Acknowledgments}

The author would like to thank the Institute for Research and Community Service, University of Riau, which has financed this activity through the Assisted Village Service scheme with Contract Number: 1363/UN.19.5.1.3//2018.

\section{Disclosure of conflict of interest}

All authors declare there is no conflict of interest in this paper. 


\section{References}

[1] Nuryani. Potensi subtitusi beras putih dengan beras merah sebagai makanan pokok untuk perlindungan diabetes mellitus [Potential substitution of white rice with brown rice as a staple food for diabetes mellitus protection]. Media Gizi Masyarakat Indonesia. 2013; 3(3): 157-168.

[2] Badan Pusat Statistik Riau [BPS-Statistics of Riau]. Riau dalam Angka. Produksi Tanaman Pangan [Riau in Numbers. Food Crops Production]. BPS-Statistics. Pekanbaru. 2017.

[3] Supangkat G. Eksistensi varietas padi lokal pada berbagai ekosistem sawah irigasi: studi di Daerah Istimewa Yogyakarta [The existence of local rice varieties in various irrigated rice ecosystems: a study in the Special Region of Yogyakarta]. Planta Tropika: Jurnal Agrosains (Journal of Agro Science). 2017; 5(1): 34-41.

[4] Notohadikusumo T. Tanah dan Lingkungan [Land and Environment]. Pusat Studi Sumberdaya Lahan. UGM [Center for the Study of Land Resources, Gadjah Mada University]. Yogyakarta. 2000.

[5] Firmansyah MA. Kebakaran Gambut Tertimbun Tergolong Paling Berbahaya [Buried peat fires are classified as the most dangerous]. BPTP Kalimantan Tengah. 2015; 9.

[6] Hanum C. Teknik Budidaya Tanaman Jilid 2 [Plant Cultivation Techniques Volume 2]. Departemen Pendidikan Nasional. Jakarta. 2008.

[7] Central Plantation Services Laboratory. Analisis Sifat Kimia Sampel Tanah [Analysis of Chemical Properties of Soil Samples]. 2019. PT Central Alam Resources Lestari. Pekanbaru. 2019.

[8] Utama MHZ. Budidaya Padi pada Lahan Marjinal [Rice Cultivation on Marginal Land. Andi offset. Yogyakarta. $2015 ; 316$.

[9] Handayani F, Sumarmiyati, NR Ahmadi. Keragaman morfologi 20 kultivar padi lokal asal Kalimantan Timur [Morphological diversity of 20 local rice cultivars from East Kalimantan]. Prosiding Seminar Nasional Masyarakat Biodiversitas Indonesia [Proceedings of the National Seminar on the Indonesian Biodiversity Society]. 2017; 3(1): 88-93.

[10] Suprihatno B. Deskripsi Varietas Padi [Description of Rice Varieties]. Balai Besar Penelitian Tanaman Padi. Badan Penelitian dan Pengembangan Pertanian. Kementerian Pertanian Skamania [Center for Rice Research. Agricultural Research and Development Agency. Ministry of Agriculture Sukamandi]. 2010.

[11] Lubis DS, AS Hanafiah, Sembiring M. Pengaruh pH terhadap pembentukan bintil akar, serapan hara N, P dan produksi tanaman pada beberapa varietas kedelai pada tanah Inseptisol di rumah kasa [Effect of $\mathrm{pH}$ on root nodule formation, nutrient uptake of $\mathrm{N}, \mathrm{P}$ and crop production in several soybean varieties on Inceptisol soil in screen house]. Jurnal Online Agroekoteknologi. 2015; 3(3): 1111-1115.

[12] Sudaryono. Tingkat kesuburan tanah ultisol pada lahan pertambangan batubara Sangatta Kalimantan Timur [Ultisol soil fertility level in Sangatta coal mining area, East Kalimantan]. J. Tek. Ling. 2009; 10 (3): $337-346$.

[13] Fauziah A. Pengembangan Benih dan Varietas Unggul Padi Sawah [Development of Superior Rice Seeds and Varieties]. Direktorat Jendral Tanaman Pangan. Kementrian Pertanian [Directorate General of Food Crops. Ministry of Agriculture]. 2014.

[14] Arraudeau MA, BS Vergara. Pedoman Budidaya Padi Gogo [Upland Rice Cultivation Guidelines]. BPTP. Sukarami. 1992.

[15] Warda. Keragaman Beberapa Varietas Unggul Baru Padi Gogo di Kabupaten Bantaeng Sulawesi Selatan [The Diversity of Several New Superior Varieties of Gogo Rice in Bantaeng Regency, South Sulawesi]. BPTP Sulawesi Selatan. 2011.

[16] Krismawati A, Z Arifin. Stabilitas Hasil Beberapa Varietas Padi Lahan Sawah [Yield Stability of Several Rice Varieties]. Badan Pengkajian dan Pengembangan Teknologi Pertanian [Agency for the Assessment and Development of Agricultural Technology]. 2011; 14(2): 84-92.

[17] Atman and Yardha. Pengaruh Jumlah Bibit Terhadap Pertumbuhan dan Hasil Padi sawah Varietas Batang Lembang [The Influence of Number of Seeds on Growth and Yield of Rice in Batang Lembang Varieties]. Prosiding Lokakarya Nasional. Percepatan Penerapan IPTEK dan Inovasi Teknologi Mendukung Ketahanan Pangan dan revitalisasi pembangunan Pertanian [Proceedings of the National Workshop. Acceleration of Alication of Science and Technology and Technological Innovation Suorts Food Security and revitalization of Agricultural development]. BPTP Jambi. 2007; 531-538. 
[18] Rasyad A. Keragaman Sifat Varietas Padi Gogo Lokal di Kabupaten Kampar Riau [Diversity of Local Gogo Rice Varieties in Kampar Regency, Riau]. Lembaga Penelitian Riau. Pekanbaru. 1997.

[19] Taslim H, S Partohardjono, Subandi. Pemupukan Padi Sawah [Rice Field Fertilization]. $1989 ; 459$.

[20] Sudaryono. Tingkat kesuburan tanah ultisol pada lahan pertambangan batubara Sangatta Kalimantan Timur [Ultisol soil fertility level in Sangatta coal mining area, East Kalimantan. J. Tek. Ling. 2009; 10 (3): $337-346$.

[21] Aksani D. Peningkatan pH Tanah pada Budidaya Padi Lahan Pasang Surut melalui Aplikasi Pupuk Cair dari Neptunia prostrate [Increasing Soil pH in Tidal Rice Cultivation through Alication of Liquid Fertilizer from Neptunia prostrata]. Prosiding Seminar Nasional Lahan Suboptimal 2016. Sriwijaya University. 2016.

[22] Hutasoit, H Yetti, AE Yulia. Pengaruh jumlah bibit pada lubang tanam dan frekuensi pengendalian gulma terhadap pertumbuhan dan produksi padi sawah (Oryza sativa L.) dengan metode SRI [The effect of the number of seeds in the planting hole and the frequency of weed control on the growth and production of lowland rice (Oryza sativa L.) with the SRI method. Jom Faperta. 2015; 2(1).

[23] Hayani, Slameto, Sopandi. Kajian Dosis Pupuk NPK pada beberapa varietas Padi di Sidorahayu Lampung Selatan [Study of NPK Fertilizer Dosage on Several Rice Varieties in Sidorahayu, South Lampung]. Prosiding Kongres Nasional VII HITI [Proceedings of the VII HITI National Congress]. Bandung. Hal. 1999; 236.

[24] Sitinjak H, Idwar. Respon berbagai varietas padi sawah (Oryza sativa L.) yang ditanam dengan pendekatan teknik budidaya jajar legowo dan sistem [Responses of various varieties of lowland rice (Oryza sativa L.) planted with the jajar legowo cultivation technique aroach and the system]. JOM Faperta. 2015; 2(2).

[25] Adimihardja A, K Sudarman, DA Suriadikarta. Pengembangan lahan pasang surut: keberhasilan dan kegagalan ditinjau dari aspek fisiko kimia lahan pasang surut [Tidal land development: success and failure in terms of physico-chemical aspects of tidal land]. Prosiding Seminar Nasional Hasil Penelitian. Menunjang Akselerasi Pengembangan Lahan Pasang Surut [Proceedings of the National Seminar on Research Results. Suorting the Acceleration of Tidal Land Development]. Balittra. Banjarbaru. Hal. 1998; 1-10.

[26] Sumardi K, M Kasim, A Syarif, N Akhir. Aplikasi ZPT untuk meningkatkan kekuatan sink tanaman padi sawah [ZPT alication to increase the sink strength of lowland rice plants]. Jurnal Akta Agrosia Edisi Khusus. 2007; (1): 26-35.

[27] Manurung, Ismunadji. Morfologi dan Fisiologi Padi [Rice Morphology and Physiology]. Pusat Penelitian dan Pengembangan Tanaman Pangan [Center for Food Crops Research and Development]. Bogor. 1998.

[28] Anhar R, E Hayati, Efendi. Pengaruh dosis pupuk Urea terhadap pertumbuhan dan produksi plasma Nutfah padi lokal asal Aceh [Effect of Urea fertilizer dose on growth and plasma production of local rice germ from Aceh]. Jurnal Kawista. 2016; 1(1): 30-36.

[29] Susanto U, AA Daradjat, B Suprihatno. Perkembangan pemuliaan padi sawah di Indonesia [Development of lowland rice breeding in Indonesia.. J. Penelitian Pertanian Tanaman Pangan. 2003; 22(3): 125-131.

[30] Efendi H, HR Simanjuntak. Respon pertumbuhan dan produksi plasma nutfah padi lokal Aceh terhadap sistem budidaya aerob [Response of growth and production of Aceh's local rice germplasm to aerobic cultivation systems. Jurnal Agrista. 2012; 16(3): 114-121.

[31] Darti E. Pengaruh cara penempatan pupuk pada beberapa varietas padi di tanah kering terhadap pertumbuhan dan produksi [The effect of the alication of fertilizers on several varieties of rice in dry soil on growth and production]. Essay. Andalas University Faculty of Agriculture. Padang. 1992.

[32] Gardner FP, RB Pearce, RL Mitchell.. Fisiologi Tanaman Budidaya [Cultivation Plant Physiology]. Universitas Indonesia Press. Jakarta. 1991.

[33] Leiwakabessy FM. Kesuburan Tanah [Soil fertility]. IPB Press. Bogor. 1998.

[34] Sutedjo MM. Pupuk dan cara pemupukan [Fertilizer and how to fertilize]. Rieneka Cipta. Jakarta. 2008.

[35] Lautt BS, MA Chozin, D Sopandie, LK Darusman. Perimbangan pati-sukrosa dan aktivitas enzim sukrosa fosfat sintase pada padi Gogo yang toleran dan peka terhadap naungan [Starch-sucrose balance and activity of the enzyme sucrose phosphate synthase in shade-tolerant and sensitive upland rice]. Hayati. 2000; 7(2): 31-34.

[36] Sasmita KD, BE Tjahjana. Hubungan kandungan hara tanah dan produksi gambir di Sumatera Barat [Relationship between soil nutrient content and gambier production in West Sumatra]. Buletin RISTRI. 2011; 2(3): 353-360. 
[37] Satria N, Wardati, MA Khoiri. Pengaruh pemberian kompos tandan kosong kelapa sawit dan pupuk NPK terhadap pertumbuhan bibit tanaman gaharu (Aquilaria malaccencis) [Effect of giving compost of oil palm empty fruit bunches and NPK fertilizer on the growth of gaharu (Aquilaria malaccensis) seedlings]. JOM Faperta. 2015; 2(1). 14 hal.

[38] Taufik S, S Baharom, RY Xiao. Predicted bahaviour of partially restrained conection with cold formed high srenght steed by 3D finite element modelling, International Journal of advanced Materials Research. Hal. 2011; 250-253.

[39] Kamal F. Parameter Genetik Beberapa Galur Introduksi Padi Sawah (Oryza sativa L) [Genetic Parameters of Several Rice Rice (Oryza sativa L) Introduced Lines. Fakultas Pertanian Universitas Andalas. Padang. 2001.

[40] Sari CPS, J Ginting, Meiriani. Pertumbuhan dan produksi padi sawah pada beberapa varietas dan pemberian pupuk NPK [Growth and production of lowland rice in several varieties and alication of NPK fertilizer]. Jurnal Online Agroekoteknologi. 2015; 3(4): 1416-1424.

[41] Subandi M, NP Salam, B. Frasetya. Pengaruh berbagai nilai EC (electrical conductivity) terhadap pertumbuhan dan hasil bayam (Amaranthus sp.) pada hidroponik sistem rakit apung (floating hydroponics system) [The effect of various values of EC (electrical conductivity) on the growth and yield of spinach (Amaranthus sp.) in a floating hydroponics system. Edisi Juli. 2015. 9 (2): 136-152.

[42] Zen S. Stabilitas hasil galur baru padi sawah preferensi konsumen Sumatera Barat Stability of yields of new lowland rice lines, consumer preferences of West Sumatra]. Jurnal Agritrop. 2007; 26(1): 1-5.

[43] Hambali A, L Iskandar. Evaluasi produktivitas beberapa varietas padi [Evaluation of the productivity of several rice varieties]. Bul Agrohorti. 2015; 3(2): 137-145.

[44] Sulansih W. Pengaruh Umur Bibit Terhadap Pertumbuhan dan Produksi Padi Sawah Varietas IR 42 dengan Metode the System of Rice Intensification (SRI) [Effect of Seedling Age on Growth and Production of Rice Field Rice Varieties IR 42 with The System of Rice Intensification (SRI) Method. Essay. Fakultas Pertanian. Universitas Riau. 2008.

[45] Atman. Pengaruh sistem tanam bershaf dengan P-starter (shafter) pada padi sawah varietas Batang Piaman [Effect of shaf croing system with P-starter (shafter) on lowland rice of Batang Piaman variety]. Jurnal Stigma. 2005; 13(4): 579- 582.

[46] Agricultural Research and Development Agency. Varietas Inpari 9 Elo. Ministry of Agriculture. Jakarta. 2017

[47] Center for Rice Research. Deskripsi Varietas Padi [Description of Rice Varieties]. Agricultural Research and Development Agency Ministry of Agriculture. 2009. 